\title{
The Mediating Effect of Trust on the Relationship between Psychological Contract and Psychological Employment Contract Breach. A Pilot Test.
}

\author{
Shakur Faruk \\ School of Business Management, Universiti Utara Malaysia, Sintok, Kedah.
}

shakuraja02@gmail.com

\begin{abstract}
Employees always expect their employers to fulfill the promises according to the conditions embedded in the employment contract being the factor binding them together because when the employer fails to meet up with the promises made, it results to psychological employment contract breach. Thus, it has become crucial for employers to uphold prior promises made to employees for the purpose of reciprocated gestures from the employees leading to increased motivation and performance in the organizations. This paper used little number of sample data in examining psychological contract, trust and psychological employment contract breach in Nigeria public universities. More so, it employs the use of SPSS (Version 24) to examine the reliability and Cronbach alpha of the measurement instruments, as well as the content and face validity. Academicians and experts were used in the instrumented assessment and the pilot study result revealed that the instruments are reliable with evidence of reasonable regularity.
\end{abstract}

\author{
Article Information: \\ Received: 25 Mar 2019 \\ Revised: $\quad 15^{\text {th }}$, Aug 2019 \\ Accepted: $\quad 6^{\text {th }}$, Sep 2018
}

\section{Introduction}

All over the world, Universities are considered as the citadel of academic excellence, knowledge, source of intellectualism and above all, the suitable environment for the grooming future leaders (Philip \& Adeshola, 2013; Cricelli, Grimaldi \& Llanes Dueñas, 2018; Subair, 2014). It serves as an institution of learning and molding good character in society. According to Ipinyomi (2013), developing countries especially Africa, put their hope in educational system to campaign for its development. Despite this, the under-developed countries have remain at the basic foundation and incessantly lack the value for the need of taking it with utmost importance (Ajaiya \& Usman, 2010; Bukola, 2011), as this led to low attachment on the relevance of the academic employment contracts thereby influencing their perception negatively on the job.

It is important to understand that one of the utmost factors to achieving the aims and objectives of any university system is the lecturer (Nwakpu, 2010), and the academic staff performance is not only centered on their qualification and competence, but also psychological fulfillment which encourages them to put in their best (Abdulsalam \& Mawoli, 2012; Istichomah, Suroso \& Dimyati, 2018). The academicians serve as key players in the university system as the survival or otherwise of any university depends on sound and dedicated lecturers. Therefore, it is expected that the government support the lecturers with the appropriate packages (improved condition of service, working tools, welfare package, promotion of qualified personnel, etc.) in accordance to their employment contract so as to withstand the security challenges bedeviling the nation but reverse is the case(Oriere, 2016; Ogunyemi, 2016). This has led to series of industrial actions and it is on this note that this study intends to look into psychological contract, trust and psychological contract breach in Nigeria public universities.

Furthermore, previous studies on psychological contract have the same opinion which shows the important role it plays in enhancing employee's perception regarding their job and employer (Ahmad \& Zafar, 2018; Leary-Kelly, Henderson, Anand, \& Ashforth, 2014; Rousseau, 1990), but it also needs further empirical research on numerous scope, various national cultures and other differences among cross-national (Rousseau \& Schalk, 2000; Westwood, Sparrow \& Leung, 2001). This is because results from previous studies carried out in other parts of the world cannot be generalized due to cultural differences. Also, results from previous studies indicated that there is significant relationship between psychological contract and psychological employment contract breach (Jamil, Raja \& Darr, 2013; Restubog.et.al, 2013; Van der, Linde \& Cockeran, 2013), while others revealed insignificant relationship (Alcover et al, 2012; Grimmer \& Oddy, 2007) and this inconsistencies necessitates the introduction of mediating variable in shedding more light on the relationship between psychological contract and psychological employment contract breach (Lo \& Aryee, 2003).

Based on the above reasons, this paper intends used trust as mediating variable on psychological contract and psychological employment contract breach so as to empirically test for pilot study in Nigeria since most of the studies on psychological contract are in 
western world and there is need for such in Nigeria. Therefore, psychological contract would serve as the independent variable, while trust is the mediating variable and psychological employment contract breach is the dependent variable in accordance to previous suggestions (Barron \& Kenny 1986; DeConinck, 2010; Lo \& Aryee, 2003).

A pilot test is a trial of using small samples size of the study for a prior test before making use of the full-scale sample of the study (Gay, Mills, \& Airasian, 2006). This study, therefore, carried out a pilot test so as to check the instrument validity, reliability and getting glimpse of the condition in identifying and adjusting the problems accordingly. A little sample size of the study was carried out accordingly. The instrument validity is the extent at which the instrument is measuring what it is supposed to measure appropriately, and measurement reliability, on the other hand, is the extent to which an instrument is free from error, consistent and stable over time and across various items in the scale (Sekaran \& Bougie, 2010). Hence, this paper shows the pilot test result with respect to psychological contract, trust and psychological employment contract breach in Nigeria public universities.

\section{Methodology}

As earlier mentioned in the previous chapter, this study is concerned with pilot test of an ongoing research using small sample of lecturers as respondents in accordance to recommendation of Malhotra (2008) which emphasized that pre-test sample size should be around 15 to 30 respondents, but it can be increased if the test involves several stages. Therefore, a total of 30 copies of questionnaires were personally distributed among lecturers, while 28 copies were completed and returned. Meanwhile, 3 copies out of the 28 copies that were returned were not properly completed and thus, not included in the analysis.

In addition, Sekaran and Bougie (2010) clearly explained that the most usual test of inter-item uniformity reliability is Cronbach's alpha coefficient. This is because the inter-item uniformity reliability is the most practical measures of pilot test, and the reliability measurement is termed to be the most popular value of Cronbach's alpha coefficient (Sekaran \& Bougie, 2010). Thus, Cronbach alpha test is carried out in this paper so as to establish and examine the internal uniformity of the tool.

\section{Measurement of Variables and Instrumentation}

The present study properly prepared a questionnaire that comprises of multiple-choice questions which are closed-ended in nature. A Likert scale is used for the questionnaires so as to measures responds perceptions in a reliable and appropriate manner (Alreck \& Settle, 1995; Miller, 1991), hence, a 5- point Likert scale was used to cover the independent, mediating and dependent variable so as to meet the requirement of measuring scales for latent construct in social science research (Churchill \& Peter 1984).

Furthermore, the variables contained in this study are psychological contract, trust, and psychological employment contract breach, as all these variables/constructs are uni-dimensional. The pilot study was divided into 1 to 4 accordingly. Section 1: Encompasses seven questions regarding lecturers' background information. Section 2: Contained a set of nine questions on employee's perception of psychological employment contract breach by their employer. Section 3: Includes thirty-three questions of employee's perception of psychological contract from employer. While section 4: Contain seven questions of the employee's level of trusting their employer. More so, only the items that are significant in answering the research questions were included in the questionnaire as responsive questionnaire were not included for the purpose of obtaining high response rate (Sekaran \& Bougie, 2010).

\section{Reliability and Validity Tests Results}

\section{Content and Face Validity}

This involves using team of specialist in the related field to test few sample representation of respondents for the purpose of passing judgment on the appropriateness of the items chosen in determining a variable (Hair, Money, Samouel \& Page, 2007; Sekaran \& Bougie, 2010; Hair et al., 2010). This entails orderly appraisal of scale in ensuring that items are theoretically measuring what it is purposely meant for. Meanwhile, in ensuring the validation of this instrument, sample was distributed to experts so as to get feedback regarding the sufficiency and appropriateness of the items under investigation. More so, few lecturers in Universiti Utara Malaysia, as well as Ph.D. students that have experience in the related field of study, were given the questionnaire for the purpose of assessment and necessary observation of the measuring instruments.

Thus, they made some observations and few words are rearranged and rephrased, for the purpose of proper construct determination, in enhancing the respondents' ability to understand and answer the questionnaires appropriately. This process of consulting experts took the period of two weeks leading to the derivation of accurate questionnaire that was administered for the pilot study.

\section{Reliability Test}

In addition to the face and content validity, it is also important to undertake a reliability test. There are different forms of reliability test but internal consistency reliability test is the most common technique used by researchers (Green \& Yang, 2015; Litwin, 1995). This is the level at which items "dangle jointly as a set" as well as having the ability of independently measuring the alike concept regarding the level at which the items are associated with each other. Cronbach's alpha coefficient is the most accepted test of inter-item consistency reliability (Sekaran \& Bougie, 2010), and thus, this study employed it to ascertain the internal consistency of the mechanism.

Checking the accuracy and consistency of instruments is crucial (Hair, Money, Samouel \& Page, 2007), despite the fact that construct measures were deduced from previous studies and literature, there is still need testing and validation (Hair et al., 2007), as carried out in this research. Also, Hair et al. (2007) made an observation that researchers usually consider a Cronbach alpha value of 0.70 as the minimum, but lower coefficients may be acceptable as well.

The study analyzed the data with the application SPSS version 24 and the result shows that the items are reliable ranging from 0.825 to 0.916 and it is in accordance with past studies that applied same measurement and found it to be reliable (Fayyazi, \& Aslani, 2015; Peng, Jien \& Lin, 2016; Rayton \& Yalabik, 2014; Sharif, Wahab \& Sarip, 2017; Robinson \& Morrison, 2000; Millward \& Herriot, 2000).

\begin{tabular}{|c|c|c|}
\hline Construct & No of items & Cronbach's Alpha \\
\hline Psychological & & 0.916 \\
\hline $\begin{array}{l}\text { Employment } \\
\text { Contract Breach }\end{array}$ & 9 & \\
\hline $\begin{array}{l}\text { Trust } \\
\text { Psychological }\end{array}$ & 7 & 0.825 \\
\hline $\begin{array}{l}\text { Psychological } \\
\text { Contract }\end{array}$ & 33 & 0.869 \\
\hline
\end{tabular}

\section{Data Distribution}

According to Tabacknich \& Fidell, (2007) as well as Pallant (2001), the general standard for the inferential statistical method is the execution of normality test. Normality implies the scores of each variable that is distributed normally (Hair et al., 2010). As suggested by Hair et al. (2012) as well as Hair et al. (2014), normality can be checked through variable values of skewness and kurtosis of the data distribution. 
This is because skewness and kurtosis have empirical measures in several statistical programs and thus, the metric variables of both Skewness and Kurtosis should fall within the range of -1.96 and +1.96 (Brown, 1997; Hair Jr, et al., 1998). Thus, the data of the present study were examined via skewness and kurtosis and it was discovered to be normal and they all fall within the normal range of -1.96 and +1.96 (Brown, 1997).

\section{Conclusion}

The purpose of this pilot study is to examine the reliability and validity of the measuring instruments for further large scale study. This study makes use of a few sample size of 25 cases for pilot test as specialist was used to effecting necessary corrections against larger study that would be conducted.

Face and content validity were examined in this study, while the implication of the study constructs would be completely examined in the main study. More so, the inter-item reliability test revealed that all the studied items under the present study were reliable and above the minimum benchmark of 0.07. Also, the skewness and kurtosis indicated that the data is normal as they all fall within the normal range.

\section{References}

Abdulsalam, D., \& Mawoli, M.A. (2012). Motivation and job performance of academic staff of State universities in Nigeria: The case of Ibrahim Badamasi Babangida University, Lapai, Niger state. International Journal of Business and Manegement, 7(14), 142-148.

Ahmad, I., \& Zafar, M. A. (2018). Impact of psychological contract fulfillment on organizational citizenship behavior: mediating role of perceived organizational support. International Journal of Contemporary Hospitality Management, (just-accepted), 00-00.

Ajaiya M. A. \& Usman A. (2010).Budgetary allocations and sectoral contributions to economic development in Nigeria. Interdisciplinary Journal of Contemporary Research in Business, 1(10), 83-94.

Alreck, P. L., \& Settle, R. B. (1995). The importance of word-of-mouth communications to service buyers. In Proceedings of American Marketing Association (Vol. 6, pp. 188-193). Chicago, IL: American Marketing Association.

Alcover, C. M., Martinez-Inigo, D., \& Chambel, M. J. (2012). Perceptions of employment relations and permanence in the organization: Mediating effects of affective commitment in relations of psychological contract and intention to quit. Psychological Reports, 110(3), 839-853.

Barron, R. M., \& Kenny, D. A. (1986). The moderator-mediator variable distinction in social psychological research: Conceptual, strategic, and statistical considerations. Journal of personality and social psychology, 51(6), 1173-1182.

Bukola, A.B. (2011).Entrepreneurship Education: An imperative for sustainable development in Nigeria. Journal of Emerging Trends in Educational Research and Policy Studies, 2(1), 1293-1312.

Churchill Jr, G. A., \& Peter, J. P. (1984). Research design effects on the reliability of rating scales: A meta-analysis. Journal of marketing research, 21(4), 360-375.

Cricelli, L., Greco, M., Grimaldi, M., \& Llanes Duenas, L. P. (2018). Intellectual capital and university performance in emerging countries: evidence from Colombian public universities. Journal of Intellectual Capital, 19(1), 71-95.

DeConinck, J. B. (2010). The effect of organizational justice, perceived organizational support, and perceived supervisor support on marketing employees' level of trust. Journal of business research, 63(12), 1349-
1355.

Gay, L. R., \& Geoffrey, E. (2006). Mills, and Peter Airasian. Educational Research: Competencies for Analysis and Applications, 8 .

Fayyazi, M., \& Aslani, F. (2015). The impact of work-life balance on employees' job satisfaction and turnover intention; the moderating role of continuance commitment. International Letters of Social and Humanistic Sciences, 51, 33-41.

Green, S. B., \& Yang, Y. (2015). Evaluation of dimensionality in the assessment of internal consistency reliability: Coefficient alpha and omega coefficients. Educational Measurement: Issues and Practice, 34(4), 1420.

Grimmer, M., \& Oddy, M. (2007). Violation of the psychological contract: The mediating effect of relational versus transactional beliefs. Australian Journal of Management, 32(1), 153-174.

Gronemus, J. Q., Hair, P. S., Crawford, K. B., Nyalwidhe, J. O., Cunnion, K. M., \& Krishna, N. K. (2010). Potent inhibition of the classical pathway of complement by a novel C1q-binding peptide derived from the human astrovirus coat protein. Molecular immunology, 48(1-3), 305-313.

Hair, J. F. (2010). Black, WC, Babin, BJ, \& Anderson, RE (2010). Multivariate data analysis, 7.

Hair, Jr., J. F., Money, A. H., Samouel, P., \& Page, M. (2007). Research methods for business. Chichester: John Willey \& Sons Ltd.

Hair, J. F., Sarstedt, M., Hopkins, L., \& Kuppelwieser, G. V. (2014). Partial least squares structural equation modeling (PLS-SEM) An emerging tool in business research. European Business Review, 26(2), 106-121.

Hair, J. F., Sarstedt, M., Ringle, C. M., \& Mena, J. A. (2012). An assessment of the use of partial least squares structural equation modeling in marketing research. Journal of the Academy of Marketing Science, 40(3), 414-433. Ipinyomi, R. A. (2013, November 6). Eventually ASUU/FGN

Faceoff Would End But For Wrong Reasons. African

Examiner.

Istichomah, I., Suroso, I., \& Dimyati, M. (2018). The effect of organizational climate, fatigue, stress and motivation on the performance of lecturers in stie Widya Gama Lumajang. MBA-Journal of Management and Business Aplication, 1(1).

Jamil, A., Raja, U., \& Darr, W. (2013). Psychological contract types as moderator in the breach-violation and violation-burnout relationships. The Journal of psychology, 147(5), 491-515.

Litwin, M. S. (1995). How to measure survey reliability and validity (Vol. 7). Sage.

Lo, S., \& Aryee, S. (2003). Psychological contract breach in a Chinese context: An integrative approach. Journal of Management Studies, 40(4), 10051020 .

Malhotra, N. K. (2008). Essentials of marketing: An applied orientation Australian: Pearson Education. Randle, WM (1995). Delivering the future: Redefining the role of banks in new competitive environment. Bank.

Millward, L., \& Herriot, P. (2000). The psychological contract in the United Kingdom. Psychological contracts in employment: cross-national perspectives, 231-249.

Miller, L. K. (1995). Genetically engineered insect virus pesticides: present and future. Journal of Invertebrate Pathology, 65(3), 211-216.

Nwakpu, E. (2010), Letter to the Executive Governor of Ebonyi State on the True Situationof Ebonyi State University and why they are on Strike.

Ogunyemi. B. (2016, July 21). We need 100,000 lecturers in Nigeria Public Universities. Vanguard Newspaper.

O’Leary-Kelly, A. M., Henderson, K. E., Anand, V., \& Ashforth, B. E. (2014). Psychological contracts in a nontraditional industry: Exploring the implications for psychological contract development. Group \& 
Organization Management, 39(3), 326-360.

Oriere, L. A (2016, February 19) Federal government won't reverse sack of 13 vice chancellors. Vanguard

Pallant, J. (2001). SPSS survival manual: A step by step guide to data analysis using SPSS for Windows (versions 10 and 11): SPSS student version 11.0 for Windows. Open University Press.

Peng, J. C., Jien, J. J., \& Lin, J. (2016). Antecedents and consequences of psychological contract breach. Journal of Managerial Psychology, $31(8), 1312-1326$

Philip, D. D., \& Adeshola, A. J. (2013). A comparative analysis of trade disputes settlement in Nigerian public and private universities. JL Pol'y \& Globalization, 18, 60 .

Rayton, B. A., \& Yalabik, Z. Y. (2014). Work engagement, psychological contract breach and job satisfaction. The International Journal of Human Resource Management, 25(17), 2382-2400.

Rousseau, D. M. (1990). Normative beliefs in fund-raising organizations: Linking culture to organizational performance and individual responses. Group \& Organization Studies, 15(4), 448-460.

Robinson, S. L. and Morrison, E. W. (2000). `The development of psychological contract breach and violation: a longitudinal study'. Journal of Organizational Behavior, 21: 5, 525-46.

Rousseau, D., Schalk, R., \& Schalk, M. R. (Eds.). (2000). Psychological contracts in employment: Cross-national perspectives. Sage.

Sekaran, U. Bougie (2010). Research methods for business: A

skill building approach.

Sharif, I., Wahab, S. R. A., \& Sarip, A. (2017). Psychological Contract Breach and Feelings of Violation: Moderating role of Age-Related Difference. International Journal of Asian Social Science, 7(1), 85-96.

Shoss, M. K., Eisenberger, R., Restubog, S. L. D., \& Zagenczyk, T. J. (2013). Blaming the organization for abusive supervision: The roles of perceived organizational support and supervisor's organizational embodiment. Journal of Applied Psychology, 98(1), 158.

Subair, S. T. (2014). University Education in Nigeria. Problem and Prospects. Florida. Journal of Educational Administration and Policy, 3(1), 1-8.

Tabachnick, B. G., Fidell, L. S., \& Ullman, J. B. (2007). Using multivariate statistics (Vol. 5). Boston, MA: Pearson.

Van der Vaart, L., Linde, B., \& Cockeran, M. (2013). The state of the psychological contract and employees' intention to leave: The mediating role of employee well-being. South African Journal of Psychology, 43(3), 356-369.

Westwood, R., Sparrow, P., \& Leung, A. (2001). Challenges to the psychological contract in Hong Kong. International Journal of Human Resource Management, 12(4), 621-651. 